\title{
Demographic and Socio-Economic Status of Rural and Urban Women in Owo Local Government Area of Ondo State, Nigeria
}

\author{
Onafowokan M. A. and Rufai O. M. \\ Health Information Management Department, Ogun State College Of Health Technology, Ilese -Ijebu Ogun \\ State.
}

\begin{abstract}
Rapid urbanization has led to an acute shortage of social amenities and poor urban living conditions and has placed a further burden on already insufficient infrastructure and services. The study assessed the demographic and socio-economic status of urban and rural women. A total of 188 households were used for the study, interviewer administered questionnaire was used for data collection. The result showed that $59.1 \%$ and $42.2 \%$ of the urban and rural households had family size of 5-7 persons and $32.9 \%$ and $55.6 \%$ had family size of more than 7 persons respectively. The Power Holding Company of Nigeria was the major source of electricity and bush was the major mode of refuse disposal. The educational status of the respondents showed that $47 \%$, $43.4 \%$ and $9.6 \%$ of the rural head of households had no education, primary education and secondary education respectively while $47.4 \%$ 45.4\% and $7.2 \%$ the rural women possessed no education, primary education and secondary education respectively. However, $56 \%$ of the urban household heads had tertiary education while $47.1 \%$ of the women had tertiary education. Socio-economic status revealed that all he rural respondents were low income while $58.8 \%$ and $18.8 \%$ of the urban households were middle and high income respectively. Therefore credit facilities and loans should be targeted at women in other to boost their trade and improve their economic status.
\end{abstract}

Key words: Demographic status, educational levels, income levels, rural, urban

\section{Introduction}

As the world's cities grow, the supply of adequate food becomes increasingly important. The number of urban households adequately fed varies from low income, through middle, to the higher income class. The rural households are usually middle income and low income, and the supply of food is usually inadequate (1). Also, rapid urbanization since the 1990s has led to an acute shortage of social amenities and poor urban living conditions and has placed a further burden on already insufficient infrastructure and services (2). According to UNDESA reported in 2009 (3) that half of all Nigerians were living in urban areas by 2010, and that proportion is projected to grow to three-quarters by 2050. In addition to this, In 2005, an estimated two-thirds of Nigeria's urban population was living in slums (4).

The consequence of this will be explosion of slum and squatter settlement amidst mass poverty and gross inequality regarding basic service provision. In such situations, the urban poor bear the brunt of insufficient resources, unemployment, substandard housing and inadequate supply of clean water and sanitation. In this context, the access, availability and provision of basic services in urban areas become an important development agenda for government, donors, and non governmental agencies.

Beside all these, there is an intrinic gender issue where poverty is concerned. One of the ways in which this is manifested is in the shift from women lead leadership to man-level leadership as one moves from subsistence farming to market driven farming. Women are important as food producers, managers of natural resources, income earner and caretakers of household food security.

\section{Methodology}

The study was carried out among urban and rural women in Owo local government area of Ondo state, Nigeria. A total of 188 women were purposively selected for the study in which 90 of them resides in the urban quarters and 98 in the rural communities. A self administered semi-structured questionnaire was used for data collection. The data collected was analyzed using statistical package for social sciences (SPSS) version 17. Frequency and percentages were generated and statistical significance was determined.

\section{Result And Discussion}

Table 1 below showed that $2.2 \%$ of the rural respondents had the family size between $2-4$ and $55.6 \%$ had the family size of 8 and above while majority of the urban family size was between 5-7 (59.1\%) 
Table 1: The Family Size of Urban Women of Childbearing Age

\begin{tabular}{cllll}
\hline & \multicolumn{3}{c}{ Urban } & Rural \\
\hline FAMILY SIZE & $\mathbf{N}$ & $\boldsymbol{\%}$ & $\mathbf{N}$ & $\%$ \\
\hline $\mathbf{2 - 4}$ & 7 & 7.9 & 2 & 2.2 \\
$\mathbf{5 - 7}$ & 52 & 59.1 & 40 & 42.2 \\
$\geq \mathbf{8}$ & 29 & 32.9 & 56 & 55.6 \\
\hline
\end{tabular}

Table 2 shows that $71.4 \%$ of the rural respondents were farmers, $45.9 \%$ of them had no electricity, $62.2 \%$ of them used well as their source of water, $95.9 \%$ of them used bush as their source of waste disposal and $74.2 \%$ of them used bush as their main type of toilet. The urban respondents on the other hand credited Power Holding Company of Nigeria (85.2\%) as the major source of energy while their primary source of portable water was well $(68.2 \%), 85.2 \%$ reported to be using refuse dump as the primary source of waste disposal and $47.7 \%$ uses water system as their main type of toilet.

Table 2: The Demographic Information of the Respondents

\begin{tabular}{|c|c|c|c|c|}
\hline \multicolumn{3}{|c|}{ Urban } & \multicolumn{2}{|c|}{ Rural } \\
\hline DEMOGRAPHIC INFORMATION & $\mathbf{N}$ & $\%$ & $\mathbf{N}$ & $\%$ \\
\hline \multicolumn{5}{|l|}{ Occupation } \\
\hline Farming & 3 & 3.4 & 70 & 71.4 \\
\hline Trading & 49 & 55.1 & 15 & 15.3 \\
\hline Civil Servant & 20 & 22.5 & 1 & 1.0 \\
\hline Artisan & 15 & 16.9 & 12 & 12.3 \\
\hline Total & 90 & 100.0 & 98 & 100 \\
\hline \multicolumn{5}{|l|}{ ENERGY SOURCE } \\
\hline Personal generator & 12 & 13.6 & 8 & 8.2 \\
\hline Rural electricity & - & - & - & - \\
\hline Power Holding Company of Nigeria (PHCN) & 76 & 86.3 & 89 & 90.8 \\
\hline Total & 90 & 100.0 & 98 & 100 \\
\hline \multicolumn{5}{|l|}{ REFUSE DISPOSAL } \\
\hline Bush & 10 & 11.4 & 94 & 95.9 \\
\hline Refuse Dump & 75 & 85.2 & 3 & 3.1 \\
\hline City Service & 3 & 3.4 & 1 & 1 \\
\hline Total & 90 & 100.0 & 98 & 100 \\
\hline \multicolumn{5}{|l|}{ WATER SOURCE } \\
\hline Spring / River & 3 & 3.4 & 2 & 2.0 \\
\hline Well & 60 & 68.2 & 12 & 12.2 \\
\hline Bore Hole & 20 & 22.7 & 61 & 61.2 \\
\hline Pipe Borne Water & 5 & 5.7 & 23 & 23.1 \\
\hline Total & 90 & 100.0 & 98 & 100 \\
\hline \multicolumn{5}{|l|}{ TOILET } \\
\hline Pit Latrines & 15 & 17.0 & 72 & 74.2 \\
\hline Bush & 3 & 3.4 & 23 & 23.7 \\
\hline VIP Latrines & 28 & 31.8 & 2 & 1 \\
\hline Water System & 42 & 47.1 & - & - \\
\hline Total & 90 & 100.0 & 97 & 100 \\
\hline
\end{tabular}

Table 3 below showed the respondents educational status of the rural respondents. About $47.0 \%$ of the head of households had no education while about $55 \%$ of the urban men had post secondary education 
Table 3: The Educational Level of the heads of households

\begin{tabular}{lcccc}
\hline & \multicolumn{2}{c}{ Urban } & Rural & \\
\hline & N & $\%$ & N & $\%$ \\
No Education & - & - & 39 & 47.0 \\
Pry Six/Modern III & 7 & 8.5 & 36 & 43.4 \\
Secondary & 24 & 29.3 & 8 & 9.6 \\
OND/NCE & 14 & 17.1 & - & - \\
University & 35 & 38.9 & - & - \\
Total & 90 & 100.0 & 83 & 100 \\
\hline
\end{tabular}

Table 4 reveals that $47.4 \%$ of the rural women had no education while $7.2 \%$ of the women had secondary education.

Table 4 The Educational Level of the women

\begin{tabular}{|c|c|c|c|c|}
\hline Education & & & Rural & \\
\hline & $\mathbf{N}$ & $\%$ & $\mathbf{N}$ & $\%$ \\
\hline No Education & - & - & 46 & 47.4 \\
\hline Pry Six/Morderm III & 19 & 19.5 & 44 & 45.4 \\
\hline Secondary & 27 & 31.0 & 7 & 7.2 \\
\hline OND/NCE & 19 & 21.8 & - & - \\
\hline University & 22 & 25.3 & - & - \\
\hline Total & 90 & 100.0 & 97 & 100 \\
\hline
\end{tabular}

Table 5 shows that all the rural respondents fell in the low income economic status while majority of the urban respondents $(58.8 \%)$ were middle income.

Table 5 Socioeconomic Status of the Family of Respondents

\begin{tabular}{lcccc}
\hline Economic status & \multicolumn{2}{c}{ Urban } & \multicolumn{2}{c}{ Rural } \\
\hline & $\mathrm{N}$ & $\%$ & $\mathrm{~N}$ & $\%$ \\
Low Income & 18 & 22.6 & 98 & 100 \\
Middle Income & 47 & 58.8 & & \\
High Income & 15 & 18.8 & & \\
\hline
\end{tabular}

Table 6 showed that $10.6 \%$ of the urban respondents said they were given money for monthly food purchase while $44.7 \%$ get $11000-19000$ for food purchase and $1.2 \%$ said they get $30000-39000$ for food purchase. On the other hand, $66.7 \%$ of the rural respondents got less than 10000 for food purchase while $29.4 \%$ does not get anything from their husbands. The table also showed that majority of the respondents add their personal income to food purchase in the family.

Table 6 The Amount Earned By the Women of Child Bearing Age

\begin{tabular}{|c|c|c|c|c|}
\hline \multirow[b]{2}{*}{ Amount given to the woman monthly } & \multicolumn{2}{|c|}{ Urban } & \multicolumn{2}{|c|}{ Rural } \\
\hline & $\mathbf{N}$ & $\%$ & $\mathbf{N}$ & $\%$ \\
\hline$<10000$ & 28 & 32.9 & 34 & 66.7 \\
\hline $11000-19000$ & 38 & 44.7 & & \\
\hline $20000-29000$ & 9 & 10.6 & & \\
\hline $30000-39000$ & 1 & 1.2 & & \\
\hline Nothing & & & 15 & 29.4 \\
\hline Total & 90 & 100.0 & 49 & 100 \\
\hline \multicolumn{5}{|l|}{ Women Addition to food purcase } \\
\hline Nothing & - & - & 3 & 4.0 \\
\hline$<10000$ & 58 & 69.0 & 72 & 96.0 \\
\hline $11000-19000$ & 14 & 16.9 & & \\
\hline $20000-29000$ & 2 & 2.4 & & \\
\hline Total & 90 & 100.0 & 75 & 100 \\
\hline
\end{tabular}




\section{Discussion}

The demographic status of the rural and urban respondents showed deficiency and inadequacy across the sectors in which the rural areas are the most affected. This is in agreement with the work of (5) who found out that domestic waste disposal is an issue that is important to the management of any urban areas. Also, a report clearly stated that only about 40 percent of Nigerians have regular access to clean water, which inadequacy affects agriculture, food security, sewage systems, manufacturing and production in general (6). Worse still, only 35 percent of Nigerians enjoy regular electricity for up to 50 percent of the time, which has a major adverse impact on most other sectors of the economy (7).

Also, According to this study, $47.0 \%$ of the head of households had no education while $47.4 \%$ of the women had no education. Education was found to significantly affect economic staus at $p<0.05$. This agrees with Ogunyemi (2010) (8) that majority of the rural dwellers are either non-literate or semi-literate. This result also agrees with the statement that rural women who receive even a minimal education are generally less than those who have no education of how to utilize available resources for the improvement of their own nutritional status and that of the family (Teller, 2000). However, over 60\% of the urban women had post primary education. This is in agreement with the work of Okolo et al (2009) (9) who found that an average urban had post-secondary education.

Table 6 showed that majority of the respondents add their personal income to food purchase in the family. Women employment increases household income, with consequent benefit to household nutrition in general and the woman's nutritional status in particular (10). Employment may increase women's status and power, and may bolster a woman's preference to spend her earnings on health and nutrition (11). Though, employed women without control over their income and decision making authority within the household are deprived of economics and social power and the ability to take actions that will benefit their own well - being (12). Studies in Africa have indicated that, all similar levels of income, households in which women have a greater control over their income are more likely to be food secure (13).

\section{Conclusion}

The study showed that there is still gross inadequacy in the infrastructural facilities available in both the rural and urban sectors of Ondo state, Nigeria. Also, the literacy level of the rural respondents are still very poor and needs urgent attention since education is one of the sure ways to improve socio- economic and demographic status of both rural and urban dwellers.

\section{Recommendations}

Efforts should be targeted at educating rural women through adult education programme and urban women should be encouraged to further their education through online and distance learning programmes. Also, free and compulsory basic education should be enforced in the rural communities in other to ensure that all children are enlisted in schools. Finally credit facilities and loans should be targeted at women in other to boost their trade and improve their economic status

\section{References}

[1]. FAO World Food Summit Corporate Document Repository, FAO, Rome (1996) Food and Agriculture organization (2000). The state of food insecurity in the world. FAO for the UN. Rome, Italy.

[2]. United Nations Population Fund (UNFPA). Programme Review and Strategy Development Report: Nigeria (New York: UNFPA, 1996).

[3]. United Nations Department of Economic and Social Affairs (UNDESA). World Urbanization Prospects: The 2009 Revision (New York: UNDESA, 2009). Retrieved June 29, 2011, from http://esa.un.org/unpd/wup/index.htm.

[4]. Population Reference Bureau. DataFinder. Retrieved June 29, 2011, from http://www.prb.org/DataFinder.aspx.

[5]. National Population Commission (Nigeria) and RTI International, 2011. Nigeria Demographic and Health Survey (DHS) EdData Profile 1990, 2003, and 2008: Education Data for Decision-Making. 2011. Washington, DC, USA: National Population Commission and RTI International.

[6]. Swaminathan, M. S. (2006). Can science and technology feed the world in 2025? Proceeding of the $13^{\text {th }}$ Australia society of Agronomy conference 10-14 September 2006, Perth, Western Australia.

[7]. Kiss, A. (1990). Living with wildlife: Wildlife resource management with local participation in Africa.

[8]. Ogunyemi, D. (2010). Rising maternal mortality to malnutrition. Retrieved March 24, 2010 from champion online edition.

[9]. Okolo, SN, Adewumi YB and Okonji MC. Current breastfeeding knowledge attitude and practice of mothers in five rural communities in the savannah region of Nigeria. Journal of Tropical Pediatrics issue 6 page 323-326. 2009.

[10]. Frazier, S. (1999. Ramsar Sites Overview: a Synopsis of the World's Wetland of International Importance. Wetlands International, Wegeningen.

[11]. Kramer, M.S. (1998). The Epidemiology of adverse pregnancy outcome. An overview Nitr. 133.1592-1596.

[12]. Ernest, H. (1999). Food security through science. Africa Recovery 13(4): 28 - 32

[13]. Maxiya -Dixon, B., Oguntona, E.B., Harris, E., Nokoe, S., Manyong, V., Akinyele, I.O. and Sanusi, R.A. (2006). Nigeria food consumption and nutrition survey (2001 - 2003. Food Instruction Booklet, Ibadan, Nigeria. Pg. $62-64$. 